\title{
The Effect of Pedagogical Knowledge Training on the Development of Inclusive Practices for Primary School Teachers: The Case of Buea Sub-Division, South West Region of Cameroon
}

\author{
Ambei Ruhama Faizefu. Ph.D. \\ Department of Educational Psychology, Faculty of Education, University of Buea, Cameroon \\ Research Consultant: Foundation of Scientific Research, Community Based Rehabilitation and \\ Advocacy on Inclusive Education" (FORCAIE-Cameroon) \\ faizefuruhama@gmail.com
}

\begin{abstract}
This quasi-experimental study focused on the pedagogical knowledge base of teachers that promotes inclusive practices in ordinary schools in Buea Sub-Division of the South West Region of Cameroon. The study was based on the framework that teacher quality is an important factor in determining gains in learner achievement in inclusive settings, even after accounting for prior learner learning and family background characteristics. Theoretically, the present study was based on six theories: Bloom's 1956 Taxonomy of Educational Objectives, B.F. Skinner's 1938 Theory of Operant Conditioning, Jerome Bruner's 1966 Theory of Instruction, Bernstein's 1990 Theory of Pedagogic Discourse, Lee Shulman's 1987 Theory of Pedagogical Reasoning and Action and The theory of planned behavior (TPB), outlined by Icek Ajzen in 1988.The sample of this study consisted of two ordinary primary schools and forty (40) ordinary primary school teachers selected from Government Practicing Primary School Buea Town (20) and Kingston Memorial Nursery and Primary Bilingual School Buea (20). The main instrument used for data collection in this study was a teacher questionnaire constructed by the researcher. The researcher also used an observation guide before and after the training as a monitoring instrument. A pre-designed EpiData Version 3.1 (EpiData Association, Odense Denmark, 2008) database which has in-built consistency and validation checks was used to enter the data. Further consistency, data range and validation checks were also performed in SPSS version 21.0 (IBM Inc., 2012) to identify invalid codes. Participants scores were analyzed using SPSS 21.0 (IBM, 2012) for descriptive (frequency of occurrence) and comparative analysis. The major findings obtained for all the components of the study, revealed that there was a slight drop in performance at the first formative evaluation, then a progression characterizing an improvement in performance from the second formative evaluation up to the post-test. Progression was the highest with knowledge on classroom management (95.0\%), followed by knowledge of individual learner characteristics $(94.4 \%)$, then knowledge on structuring lesson objectives to respond to diversity (93.8\%), knowledge on classroom assessment (91.3\%) while the least progression was recorded with teacher attitude toward inclusive education (71.3\%) and this difference was statistically significant $\left(\chi^{2}=9.60\right.$; $d f=4 ; P=0.048)$. Consequently, it was realized that all the teachers who took part in the training improved their skills after the intervention. It was therefore concluded that pedagogical knowledge training had a great influence on development of inclusive practices by ordinary primary school teachers. The major recommendation made based on the finding was that: teacher trainers should take as a matter of responsibility the integration of pedagogical knowledge training for inclusion in teacher training programmes. The study has also shown that when this is done effectively it will result in an improvement in pedagogical skills that will eventually lead to inclusive best practices in our ordinary primary schools. The study concludes that pedagogical skill training has become a popular adjunct treatment for developing pedagogical skills that will lead to inclusive best practices in ordinary schools. Presently, pedagogical knowledge training is best viewed as an experimental intervention. The theoretical structure of pedagogical knowledge is incomplete resulting in problems in definition, measurement, and design. Specifically, further research is necessary to resolve issues regarding for example, duration of training, assessment instruments, packaging of training programmes, and contextual variables.
\end{abstract}

\section{INTRODUCTION}

The imperative in recent years about improving learner outcomes is also about improving the quality of the teaching workforce. In recent years, however, recruiting and retaining quality teachers has become a challenge in many countries all over the world. In addition to the ageing of the teaching workforce, some countries experience high rates of attrition among new teachers and a shortage of 
quality teachers in high demand subject areas and disadvantaged schools. There is also concern about attracting high achieving and motivated candidates into teacher education programmes and the lowering of qualification requirements in the certification and licensing of new teachers.

Issues such as these have an impact on the quality of the resulting teaching workforce that is tasked with improving learner outcomes. For example, the ageing of the teacher workforce entails the loss of experienced teachers through retirement. High attrition rates among new teachers is costly to the system and may prompt education authorities to fill teacher shortages by lowering qualification requirements for the certification of new teachers or by assigning teachers to teach subjects, specific learners or classes for which they were not trained. In such cases, the quality of the teaching workforce is negatively affected.

\section{BACKGROUND TO THE STUDY}

Underlying the process of inclusion is the assumption that the general classroom teacher has certain knowledge and understanding about the needs of different learners, teaching techniques and curriculum strategies. Florian and Rouse (2009) state: 'The task of initial teacher education is to prepare people to enter a profession which accepts individual and collective responsibility for improving the learning and participation of all children'. Savolainen (2009) notes that teachers play an essential role in quality education and quotes McKinsey and Company who say: 'the quality of an education system cannot exceed the quality of its teachers'. Studies suggest (Sanders and Horn, 1998; Bailleul et al., 2008) that the quality of the teacher contributes more to learner achievement than any other factor, including class size, class composition, or background. The need for 'high quality' teachers equipped to meet the needs of all learners becomes evident to provide not only equal opportunities for all, but also education for an inclusive society. Reynolds (2009) says that it is the knowledge, beliefs and values of the teacher that are brought to bear in creating an effective learning environment for pupils, making the teacher a critical influence in education for inclusion and the development of the inclusive school. Cardona (2009) notes that concentration on initial teacher education would seem to provide the best means to create a new generation of teachers who will ensure the successful implementation of inclusive policies and practices.

The OECD Report 'Teachers Matter' recognises that the demands on schools and teachers are becoming more complex as society now expects schools to deal effectively with different languages and student backgrounds, to be sensitive to culture and gender issues, to promote tolerance and social cohesion, to respond effectively to disadvantaged students and students with learning or behavioural problems, to use new technologies, and to keep pace with rapidly developing fields of knowledge and approaches to student assessment. Teachers, therefore, need confidence in their ability and the knowledge and skills in inclusive education to meet the challenges that they will encounter in the present school climate (Carroll, Forlin and Jobling, 2003).

School-based training for teachers, aimed at supporting school development, can be particularly powerful in the early stages of the move towards more inclusive education. Many successful training programmes, therefore, have been based around providing external support to schools and at the same time enabling teachers in those schools to support each other (UNESCO, 2001). A related issue, which is increasingly emerging in the literature, and particularly in evaluations of education projects/programmes, is the overall lack of practical, hands-on learning that teachers and trainee teachers are exposed to. This is particularly the case with pre-service training, which in many countries remain heavily biased towards learning the theory of inclusive education without opportunities to practice and gain confidence with teaching methods needed to support diverse learners. Research into pre-service training in low-income countries suggests that the dynamic linking of college-based learning to its application in the classroom is the exception rather than the rule (Matteson, 2006).

However, even in-service training provision can fail to offer school/classroom-based learning opportunities, instead focusing on learning theory in a workshop setting. The Rewrite the Future Programme is an initiative on improving literacy of teachers, supported by Save the Children Fund (2012). The training offered in many of the countries has focused on curriculum content, teaching methodology, child rights and teaching without physical and humiliating punishment, active teaching and learning methods, and language courses. An evaluation of the programme, covering Angola, Afghanistan, Nepal and South Sudan, "found that school-based training and cluster-based systems were proving effective in changing teacher beliefs and pedagogic practices and improving attendance 
and completion rates, with Angola showing the largest improvement in learning outcomes between 2008 and 2010" (Save the Children, 2012,). In Kyrgyzstan from 2003, training was conducted in a number of 'pilot professional development schools' and also 84 cluster schools. Resource trainers acted as mentors to existing teachers in mainstream schools, and there was much sharing of experience at seminars. This helped teachers to tackle many existing obstacles to inclusion. The next step was to introduce the Index for Inclusion. This resource pack helps schools to change policies, practices and cultures within schools. Co-ordination of 44 groups of teachers, parents, administrators and children were formed. In addition, a course for university students was developed entitled 'Inclusive Education Principles and Practices.' This was delivered by the Resource Trainers (Djumagulova, 2006).

Shenkuti and Focas Licht (2005) report on a project in Ethiopia supported by Save the Children through which resource teachers assist classroom teachers to find ways to include excluded groups in the learning process. Resource and classroom teachers received in-service training on the idea of 'presence, participation and achievement' - three essential elements of inclusive education. As part of the training, the teachers had to go back to their classes and do observation and investigation work (into 'presence, participation and achievement'). They presented case studies at the next workshop, and continued to do more observations and investigations after that. At a third workshop, teachers learned about action research (the 'look-think-act 'process), and were asked to return to their schools and carry out a simple action research cycle - identifying and analysing a barrier to inclusion and experimenting with some actions. At a fourth workshop teachers discussed their experiences, shared ideas and motivated each other to keep doing more action research to learn more about, and solve, more inclusion challenges. This approach to practical training not only helped teachers to respond better to children at risk of exclusion, but also helped teachers to start working together on solving problems, where previously they had all worked in isolation (and as a result had felt over-burdened).

UNESCO's Policy Guidelines on Inclusion in Education (2009) support the move towards schoolbased teacher education and highlights the importance of a shift away from theoretical pre-service teacher education towards 'continuous in-service development' of teachers. This is linked to the principle of 'universal design', meaning design that is appropriate for all, regardless of age, ability, characteristics. This is a principle that is promoted in the United Nations Convention on the Right of Persons with Disabilities (2006). However, Rouse (2012) indicates that institutions have not transformed their programmes to reflect this principle, despite the reality of diversity in schools. Theory is important in the development of inclusive attitudes and values as part of a move to more school placement in initial training is welcome. This will only be as good the understanding of inclusion and the quality of provision for children with disabilities often the best professional development can be undercut by teacher's conservative ethos and attitudes. To be effective attention must be paid to a structured plan of post training implementation.

However, in evaluating UNESCOs efforts in teacher education for inclusion, Tomlinson et al (2004) highlight some of the downsides to cascade training. "The cascade model was common but there are some dangers inherent in it: in that the message can become more diluted and potentially distorted or inaccurate the further down the cascade" (Tomlinson, Ridley, Fletcher-Campbell, 2004). Stubbs (2011), in reviewing teacher education for inclusion, rejects the cascade approach (a cost effective means of introducing educational change to large numbers of teachers) and points out that: "One of the main criticisms from teachers in many countries is that their initial training (and even any subsequent in-service training) involved insufficient or irrelevant practical experience in the classroom.

The practical experience needs to reflect the theoretical input. In relation to inclusion, this means that trainee teachers need experience of working collaboratively in inclusive settings, being aware of their own assumptions and behaviours, and practising problem-solving and creative solutions" (Stubbs, 2011). In a tightly controlled approach where implementation by the participants is monitored cascade training can be highly successful. For example the first attempt to use behaviourist approaches to children with severe learning difficulty (SLD) -the Education for the Developmentally Young- run by the Hester Adrien Research Centre in Manchester managed to launch this method into regular and equally successful, use in schools across England from a one week training course for one staff member from each local authority. This was made more incredible because a large part of the training was in schools with children with SLD. (McBrien, J, 1981). 
A qualitative study in the Kwa Zulu Natal Province of South Africa by Ntombela (2009) also highlighted the problems with a cascade approach. The research examined the extent to which, and the ways in which teachers in the Philani district were trained for the implementation of the Department of Education's 2001 Education White Paper 6 on Special Needs Education. The findings suggest that the cascade model was ineffective for disseminating innovations and preparing teachers for implementing these innovations. Teachers did not acquire adequate understanding of inclusive education and so the desired re-culturing of schools and classrooms did not occur - with knock-on implications for the implementation of inclusive school and classroom policies and practices. The World Bank has provided a useful list of the advantages of cascade training for teachers. These advantages include: participatory flexibility, field based and can train large numbers of teachers in a relatively short period of time, makes only moderate demands on professional training resources, is cost effective and empowering.

Since the adoption of the Cameroon's New Education Sector Strategy (2010-2020), the Ministries of Education, in collaboration with national and international partners are giving considerable attention to making the Cameroon school curriculum as friendly as possible for all learners. Sightsavers, Cameroon, an international non-governmental organization is in the forefront of this challenge and has provided remarkable initiative and leadership in terms of resource mobilization, in-service teacher training and advocacy (Tambo, 2014). For example, following recommendations of a study conducted by Tchombe, 2012) on situational analysis on the policies, practices and barriers to inclusive education in Primary Education Sector in Cameroon, Sightsavers commissioned a review of the Cameroon's primary school curriculum. This review was followed by the organization, in collaboration with the Ministries of Basic and Secondary Education, of a workshop in Ebolowa from the 18 to 20 December 2013 to develop an operational plan for putting in place a pilot project on inclusive education in selected primary schools in Cameroon.

As an important step in this direction a consultancy team led by Professor Leke Tambo was assigned the tasked to prepare a project curriculum module for enhancing the capacity of primary school teachers, head teachers and inspectors in the implementation of inclusive teaching and learning in pilot schools. The Terms of Reference (TOR) for this project required the consultancy to "design inservice training modules on inclusive education to equip teachers, head teachers as well as school inspectors with appropriate skills to ensure effective teaching and learning for pupils with disabilities within the inclusive classrooms in selected pilot schools in the South West Region of Cameroon where Inclusive Education will be implemented.

The outcome of this project was a training workshop to train teachers and head teachers selected from five pilot schools in the South West Region of Cameroon organized in Limbe in December, 2014 by the Ministry of Basic Education with technical and financial assistance from Sightsavers, Cameroon. As a follow up to this imitative, Shey (2015), conducted a study on effective teaching practices that can assist ordinary teachers in meeting the needs of learners with disabilities in ordinary schools in the South West Region of Cameroon. Participants were 87 ordinary school teachers from 5 pilot primary schools selected for in-service training on Inclusive Education by the Ministry of Basic Education and Sightsavers, Cameroon. Results showed a change of attitude on the teaching of children with disabilities by ordinary school teachers.

\section{Statement of the Problem}

One of the main conceptual divides in the world today, is between those who perceive inclusive education as a problem (or string of problems) that needs to be solved; and those who see it as a 'driver' to improve education for all. In terms of teacher education, a perception of inclusive education as a problem to be solved may translate into the delivery of a relatively small number of separate training courses designed to help teachers learn how to solve a relatively narrow range of predicted inclusion problems. On the other hand, a perception of inclusive education as a driver for more far-reaching education system change may lead to reform of teacher education so that inclusion (and related principles of quality, flexible, participatory, learner-centred teaching) is embedded throughout all training. In Cameroon some research have been done on the area of teachers perspective on inclusive practices but no research exist on the pedagogical training of teachers to enhance inclusive practices. This is a gap in literature that this research was set out to address.

Teacher training institutions in Cameroon have not reformed their programmes using the principles of universal design to ensure that inclusion is an essential element that is addressed throughout the 
training programme. They have held back progress in training teachers to acquire the useful competencies for inclusive practices. Teachers in Cameroon still express fear, anxiety and reluctance to include learners with special needs in the school system. There is a general feeling that they don't have the time, preparation, resources and skills needed in teaching children with special needs in the general education classrooms. This has contributed to ordinary teachers' lack of competencies in reducing barriers to learning and participation for all learners, not only for those with impairments but those who are categorised as 'having special educational needs'. It is against this backdrop that a study was proposed on the effect of pedagogical knowledge training on the development of inclusive practices for primary school teachers in the South West Region of Cameroon.

\section{OBJECTIVES OF THE STUDY}

Specifically, the study sought to:

- Investigate the relationship between teachers' knowledge of classroom management and the establishment of routines that free up time for small groups and individual instructions in ordinary classrooms.

- Determine the influence of knowledge of classroom assessment on teachers' ability to set high expectations for all learners in ordinary classrooms.

\section{Theoretical Considerations}

Theoretically, the present study was based on six theories: Bloom's 1956 Taxonomy of Educational Objectives, B.F. Skinner's 1938 Theory of Operant Conditioning, Jerome Bruner's 1966 Theory of Instruction, Bernstein's 1990 Theory of Pedagogic Discourse, Lee Shulman's 1987 Theory of Pedagogical Reasoning and Action and The theory of planned behavior (TPB), outlined by Icek Ajzen in 1988.

Bloom's Taxonomy was created in 1956 under the leadership of educational psychologist Dr Benjamin Bloom in order to promote higher forms of thinking in education, such as analyzing and evaluating concepts, processes, procedures, and principles, rather than just remembering facts (rote learning). It is most often used when designing educational, training, and learning processes. The committee identified three domains of educational activities or learning (Bloom, et al. 1956):

- Cognitive: mental skills (knowledge)

- Affective: growth in feelings or emotional areas (attitude or self)

- Psychomotor: manual or physical skills (skills)

Since the work was produced by higher education, the words tend to be a little bigger than we normally use. Domains may be thought of as categories. Instructional designers, trainers, and educators often refer to these three categories as KSA (Knowledge [cognitive], Skills [psychomotor], and Attitudes [affective]). This taxonomy of learning behaviors may be thought of as "the goals of the learning process." That is, after a learning episode, the learner should have acquired a new skill, knowledge, and/or attitude.

Their compilation divides the three domains into subdivisions, starting from the simplest cognitive process or behavior to the most complex. The divisions outlined are not absolutes and there are other systems or hierarchies that have been devised, such as the Structure of Observed Learning Outcome (SOLO). However, Bloom's taxonomy is easily understood and is probably the most widely applied one in use today. By the 1920s, John B. Watson had left academic psychology and other behaviorists were becoming influential, proposing new forms of learning other than classical conditioning. Perhaps the most important of these was Burrhus Frederic Skinner. Although, for obvious reasons he is more commonly known as B.F. Skinner. Skinner's views were slightly less extreme than those of Watson (1913). Skinner believed that we do have such a thing as a mind, but that it is simply more productive to study observable behavior rather than internal mental events.

The work of Skinner was rooted in a view that classical conditioning was far too simplistic to be a complete explanation of complex human behavior. He believed that the best way to understand behavior is to look at the causes of an action and its consequences. He called this approach operant conditioning. Operant Conditioning deals with operants - intentional actions that have an effect on the surrounding environment. Skinner set out to identify the processes which made certain operant 
behaviours more or less likely to occur. Skinner's theory of operant conditioning was based on the work of Thorndike (1905). Edward Thorndike studied learning in animals using a puzzle box to propose the theory known as the 'Law of Effect'. Jerome Bruner (1915-) was one of the 20th century's most influential educational psychologists. Here, he writes about the process of pedagogy. He describes the key instructional components of curriculum: its sequence of activities in which learners become self-sufficient problem-solvers: Instruction consists of leading the learner through a sequence of statements and restatements of a problem or body of knowledge that increase the learner's ability to grasp, transform, and transfer what he is learning. In short, the sequence in which a learner encounters materials within a domain of knowledge affects the difficulty he will have in achieving mastery.

If it is true that the usual course of intellectual development moves from enactive through iconic to symbolic representation of the world, it is likely that an optimum sequence will progress in the same direction. Optimal sequences cannot be specified independently of the criterion in terms of which final learning is to be judged. A classification of such criteria will include at least the following: speed of learning; resistance to forgetting; transferability of what has been learned to new instances; form of representation in terms of which what has been learned in terms of cognitive strain imposed; effective power of what has been learned in terms of its generativeness of new hypotheses and combinations. Instruction is a provisional state that has as its object to make the learner of problem-solver selfsufficient. The tutor must correct the learner in a fashion that eventually makes it possible for the learner to take over the corrective function himself. Otherwise the result of instruction is to create a form of mastery that is contingent upon the perpetual presence of the teacher.

The term 'official pedagogic discourse' is derived from the work of British sociologist Basil Bernstein (1924-2000), who used it to categorize State discourses on education as revealed in government policy documents and statements, formal state-approved curricula, inspection and examination criteria. Official pedagogic discourse, Bernstein argues, establishes particular social relations between government agencies and those active in the field of education, including educational researchers and teacher trainers as well as teachers and regional administrators, offering each group more or less status and more or less agency in using different forms of pedagogic discourse, knowledge and practice. Through official pedagogic discourse, he argued, the State constructs boundaries between different subject areas; between different types of pedagogic institution; and between different categories of learner, offering each access to selected forms of legitimate knowledge. It thus not only impacts upon curriculum and classroom practices, but also offers different forms of specialized consciousness, and thus helps to construct different identities for different categories of learners.

However, according to Bernstein teachers are themselves acquirers of particular forms of what Bernstein calls 'official pedagogic discourse', theories of learning and pedagogy usually recontextualised in training courses, government policies, syllabus documents and then embedded in the craft knowledge teachers pass on to one another through their talk and practice. Power relations thus construct what is legitimate or not in classrooms, establishing a particular social order. Thus, through pedagogic discourse and its roots in and relationships to official pedagogic discourse, Bernstein attempts to explain the link between the micro-level of interactions between teachers and learners in the classroom and the macro-level of policy and state control.

Lee Shulman's theory of pedagogical reasoning and action is related to his theory of pedagogical content knowledge and includes the following components: comprehension; transformation (preparation, representation, selection, and adaptation and tailoring to student characteristics); instruction; evaluation; reflection; and new comprehensions. The theory was presented to fourth-year Bachelor of Education (Secondary) business studies students at the University of Melbourne (Victoria, Australia) enrolled in a course linking discipline studies and education studies. The model was presented as a set of processes of central importance to the development of pedagogical content knowledge. Two assignments were made focusing on the model - one task required identification of a concept and a curriculum context and writing a report on ideas for the transformation of that concept for teaching purposes, and the other task required transformation of subject matter into a cohesive package of student exercises and activities, which are conceived as a particular form of representation of subject matter. Shulma's theory was seen as accessible and practical by almost all the pre-service teachers, as being robust and adaptable across specialist subject fields, and as having built-in variety through the widely inclusive notions of representational repertoire and instructional repertoire and combinations of the two. These two theories that form the base of this work are looked into extensively in the theoretical review section of chapter two of this study. 
The theory of planned behavior (TPB), outlined by Icek Ajzen in 1988, is an extension of the theory of reasoned action in that it identifies the importance of assessing the amount of control an individual has over behaviors and attitudes (perceived behavioral control). The TPB takes into account that all behavior is not under volitional control and that behaviors are located at some point along a continuum that extends from total control to a complete lack of control. Control factors include both internal factors (such as skills, abilities, information, and emotions) and external factors (such as situation or environmental factors). The components of the model, as they relate to behavioral intention, include attitude toward the behavior, subjective norms, and perceived behavioral control.

This study considered that learner factors are part of, and independent with, the teaching-learning process. This implies that a teacher's knowledge goes beyond mere knowledge of content and classroom management, and should also include knowledge of learners and learning. Therefore, teacher pedagogical knowledge was conceptualized in this study as the pedagogical knowledge base of teachers that includes all the cognitive knowledge for creating effective teaching and learning environment for inclusive education practices. The general pedagogical knowledge of teachers (principles and strategies of classroom management and organization that are cross-curricular) was considered preferable in this study than the pedagogical content knowledge (the knowledge which integrates the content knowledge of a specific subject and the pedagogical knowledge for teaching that particular subject) because its psychological component account for the fact that learning occurs in a social context and learning success depends on the general cognitive and affective characteristics of individual learners.

The main indicators of teacher pedagogical knowledge used in this study were:

- Knowledge of classroom management. This was operationalized in the study as having a command of various teaching methods, knowing when and how to apply each method, maximizing the quantity of instructional time, handling classroom events, teaching at a steady pace, and maintaining clear directions in learning.

- Knowledge of classroom assessment. That is, Knowledge of different forms and purposes of formative and summative assessments, knowledge of how different frames of reference (e.g., social, individual, differentiated and criterion-based) impact learners motivation to learn in inclusive settings.

- Structure. Structuring of learning objectives, and providing feedback

- Knowledge of individual learner characteristics. Having knowledge of the sources of learner cognitive, motivational and emotional heterogeneity.

- Teachers' attitude. Change of teachers' mindset in dealing with heterogeneous learning groups in the classroom.

\section{Conceptual Reflections}

The key conceptual question that may arise from this operationalisation of general pedagogical knowledge is whether a cross-cultural valid instrument of teacher knowledge can be developed for inclusive education in Cameroon. This is because Cameroon has two sub-systems (the Anglophone and the Francophone sub-systems) of education. Since the way the brain processes information should be independent of the cultural context, by adapting a cognitive-psychological approach to teaching and learning, we assume that there is a fundamental pedagogical knowledge base for creating effective teaching-learning situations that is independent from culture. This hypothesis has, in fact, been tested in studies which show that a standardized instrument designed to investigate general pedagogical knowledge is valid cross-culturally (Carroll et al., 2003).

Conceptualizing teacher pedagogical knowledge sometimes referred to as teacher knowledge base is a complex issue that involves understanding key underlying phenomena such as the process of teaching and learning, the concept of knowledge, as well as the way teachers' knowledge is put into action in the classroom. Several models exist that capture the complex process of teaching and learning. Some models see learning as a change in the learner's experience or knowledge that results from a change in the learner's environment. Some approaches consider the teaching learning process only from the perspective of teaching, while others take into account the learner's input in the process as well. In front of every teacher there are many demands and expectations set from professional and social 
environment in which they should rethink about self and vocation, define long term goals of pedagogical acting, knows the way of student learning, thinking, feeling and acting. Also, teachers develop skills that enhance personal satisfaction and effectiveness, but also knowledge and skills that encourage student self esteem. Complexity of teacher work demands competencies for every day dealing with student learning, emotional and behavioral characteristics (Carroll et al., 2003).

This study described teacher competency as a complex combination of different knowledge, skills, understanding, values, attitudes and desire which will lead to effective inclusive best practices in Cameroon. It is necessary to understand the pedagogical competencies of teacher as continuing process which is permanently submitted to evaluation through the interaction with coworkers, students, parents and others (Ljubetić \& KostovićVranješ, 2008). Inclusive education assumed identification and elimination of existing and possible sources of exclusion or separation which represent limitation of opportunities for all students and in the same time examines features of school, teachers, students, teaching and learning (Slee, 2000).

The study looked at some variables that have the most influence on the process of inclusion. Related to teacher education the following indicators were highlighted as competencies needed in order to build inclusive best practices in Cameroon ordinary schools. These competencies are:

- Clearly communicating expectations that engage all learners in learning.

- Setting high expectations for all learners.

- Establishing routines that free up time for small group and individual instructions.

- Spending time with learners who are struggling.

- Developing collaborative ways of working.

Teacher quality is an essential factor in learning (Blanton et al., 2003). Considering the teacher as the most important factor of inclusive education process, he has an obligation to create appropriate and stimulating environment for learning. In dealing with professional demands on creating opportunities for easily learning, teacher has to possess specific professional and personal competencies. Personal competencies could be observed through the attitudes and motivation for teaching learners with special educational needs in regular schools settings and professional competencies through knowing the characteristic of children with special needs, recognizing abilities for and ways of learning. In the context of building an inclusive process in Cameroon, schools and classrooms meet various learners and challenges to deal with. Learners with special educational needs are included in regular schools with their peers. Some schools like in the case of nursery education have assistants to help in the classroom as only support to learners. The most of schools don't have any support, so the teachers manage with range of different demands in the classrooms. These issues all put together forms the background problem of the present study.

\section{RESEARCH DESIGN}

The experimental design was adopted. In the experimental method, the standard procedure is to manipulate one variable and then measure its effects on another. There are two general categories of the experimental design, that is, the true experimental design and the quasi experimental design. The category adopted for this study was the quasi-experimental design and the type of quasi-experimental design used was the Pre-Post Test Design with Non-Randomized Experimental and Control Groups.

Quasi-experimental designs use comparison groups than randomly assigned control groups as the baseline against which net programme impacts can be measured. In a quasi-experimental design, the researcher substitutes statistical "controls" for the absence of physical control of the experimental situation. The three most common sources for such comparison groups are: (1) eligible nonparticipants in the same community, (2) individuals similar to the participants from an existing data base that contains the outcome measures of interest, and (3) individuals in a matched comparison site who would have been eligible for the programme if it were in that site. Evaluations using these kinds of comparison groups can effectively test for the effects of programme participation on outcomes under certain conditions. New analytical approaches can be used to control statistically for the effects of potential differences between treatment and comparison groups. These approaches require data on the outcomes of interest and their potential determinants for a period prior to programme implementation. If the data is available, models of pre-programme differences between the two groups 
The Effect of Pedagogical Knowledge Training on the Development of Inclusive Practices for Primary School Teachers: The Case of Buea Sub-Division, South West Region of Cameroon

can be estimated and tested and the results can be used to interpret post programme differences between the treatment and the comparison group populations (Heckman, Hotz, \& Dabos, 1987)

Breakwell, Hammond and Fiffe-Schaw (2004) comment that quasi experiments are often the best one can hope for as one does not always have any real ability to control the independent variables. There is always a possibility that any effects one shows are due to unforeseen confounding variables.

Table1. The Pre-Post Test Design with Non-Randomized Experimental and Control Groups

\begin{tabular}{|l|l|l|l|l|l|}
\hline $\begin{array}{l}\text { Group } \\
\text { (Independent) }\end{array}$ & Pre-test & Experimental & \multicolumn{2}{|l|}{ Mid Test } & $\begin{array}{l}\text { Post-Test } \\
\text { (Formative Evaluation) }\end{array}$ \\
\hline G1 & Q1 & X & Q2 & Q3 & Q4 \\
\hline G2 & Q1 & & & & Q4 \\
\hline
\end{tabular}

Table 1 above is explained as follows:

1. X represents the independent variable, which was referred to as the experimental variable. The experimental variable has been put into a master plan of activities relating to each variable. Each sub-section of the master plan reflects training skill activities relating to a variable and a hypothesis.

2. Q1, Q2, Q3 and Q4 represent the dependent variable before and after the manipulation of the independent variable $\mathrm{X}$. In this study it represents the pre-test, first formative evaluation, second formative evaluation and post-test respectively, administered before and after the experimental treatment.

3. G1 and G2 represent the experimental and control groups respectively.

\section{Population of The Study}

The population of this study was made up of three hundred and eighty nine (389) Ordinary Primary Schools and two thousand eight hundred and eighty one (2881) ordinary primary school teachers (Regional Delegation of Basic Education, Statistic Year Booklet, 2014-2015) in Fako Division of the South West Region of Cameroon. Therefore, the target (research) population consisted of one hundred and twenty eight (128) ordinary primary schools and one thousand and fifty one (1051) ordinary primary school teachers (Regional Delegation of Basic Education, Statistic Year Booklet, 2014-2015) in Buea Sub-Division. Meanwhile, the accessible (sampled) population involved all teachers in Government Practicing Primary School Buea Town (20) and Kingston Memorial Bilingual Nursery and Primary School Buea (20).

\subsection{Sample and Sampling Procedure}

This section of methodology describes the strategies that were used in selecting the representative elements from the accessible population, that is, the respondents, and the participating schools. Fraenkel and Wallen (2000) define a sample in a research study as any group on which information is obtained. They go further to say that the larger group to which one hopes to apply the results of a study is the population. The sample of this study consisted of two ordinary primary schools and forty (40) ordinary primary school teachers selected from Government Practicing Primary School Buea Town (20) and Kingston Memorial Bilingual Nursery and Primary School Buea (20).

Table2. Showing Sample of the Study

\begin{tabular}{|l|l|l|}
\hline Name of School & $\begin{array}{l}\text { Number of Teachers in } \\
\text { Experimental Group }\end{array}$ & $\begin{array}{l}\text { Number of Teachers in Control } \\
\text { Group }\end{array}$ \\
\hline $\begin{array}{l}\text { Government Practicing School, } \\
\text { Buea Town }\end{array}$ & 10 & 10 \\
\hline $\begin{array}{l}\text { Kingston Memorial Bilingual } \\
\text { Nursery and Primary School }\end{array}$ & 10 & 10 \\
\hline Total & $\mathbf{2 0}$ & $\mathbf{2 0}$ \\
\hline
\end{tabular}

Table3. Experimental Group

\begin{tabular}{|l|l|l|l|}
\hline School & Number of Male & Number of Female & Total \\
\hline GPPS Buea Town & 03 & 07 & 10 \\
\hline KMBNPS Buea & 02 & 08 & 10 \\
\hline Total & $\mathbf{0 5}$ & $\mathbf{1 5}$ & $\mathbf{2 0}$ \\
\hline
\end{tabular}




\subsection{Interpretation of Table 3}

Table 3 above indicates the number of teachers by sex assigned to the experimental group per school. In Government Practising Primary School (GPPS) Buea Town, three (03) male teachers and seven (07) female teachers were assigned to the experimental group giving a total number of ten (10) teachers. Meanwhile in Kingston Bilingual Memorial School (KMBNPS) Buea two (02) male teachers and eight (08) female teachers were also assigned to the experimental group giving a total number of ten (10). Therefore, the total number of teachers in the two schools assigned to the experimental group was twenty (20).

Table4. Control Group

\begin{tabular}{|l|l|l|}
\hline School & Number of Males & Number of Females \\
\hline GPPS Buea Town & 01 & 09 \\
\hline KBMNPS Buea & 02 & 08 \\
\hline Total & $\mathbf{0 3}$ & $\mathbf{1 7}$ \\
\hline
\end{tabular}

\subsection{Interpretation of Table 4}

Table 4 above indicates the number of teachers by sex assigned to the experimental group per school. In Government Practising Primary School (GPPS) Buea Town, one (01) male teacher and nine (09) female teachers were assigned to the control group giving a total number of ten (10) teachers. Meanwhile in Kingston Bilingual Memorial School (KMBNPS) Buea two (02) male teachers and eight (08) female teachers were also assigned to the control group giving a total number of ten (10). Therefore, the total number of teachers in the two schools assigned to the control group was twenty (20).

As indicted by tables 3 and 4 above, out of the forty teachers who took part in the study, twenty were assigned to the experimental group (intervention group) meanwhile the other twenty were assigned to the control group. Ten teachers in each school assigned to the experimental group took part in the training programme. These numbers of teachers were selected to take part in the training because of the researcher's conviction that more than ten teachers can be too disruptive to control, and thus become counterproductive. Small groups also give teachers a chance to observe others, practice with colleagues and receive feedback. It is on the basis of this that ten participants were selected from each school for training.

\section{SUMMARY OF FINDINGS}

Research hypothesis one: There is no significant relationship between teachers' knowledge of classroom management and the establishment of routines that free up time for small groups and individual instructions in ordinary classrooms.

Comparing progression between pre-test and post-test for Knowledge on classroom management

Table5. Comparing progression between pre-test and post-test for Knowledge on classroom management

\begin{tabular}{|c|c|c|c|c|c|c|}
\hline \multirow{3}{*}{$\begin{array}{l}\text { Knowledge on } \\
\text { classroom } \\
\text { management }\end{array}$} & \multicolumn{5}{|c|}{$\begin{array}{l}\text { Cumulative progression (in percentage of those with positive } \\
\text { change in score) }\end{array}$} & \multirow{3}{*}{$\chi 2$-test } \\
\hline & \multicolumn{4}{|c|}{ Experimental group $(\mathrm{N}=20)$} & \multirow{2}{*}{$\begin{array}{l}\begin{array}{l}\text { Control } \\
\text { group } \\
(\mathrm{N}=20)\end{array} \\
\text { Pre-test Vs } \\
\text { post test }\end{array}$} & \\
\hline & $\begin{array}{l}\text { Pre-test } \\
\text { to first } \\
\text { formative }\end{array}$ & $\begin{array}{l}\text { First } \\
\text { formative } \\
\text { to second } \\
\text { formative }\end{array}$ & $\begin{array}{l}\text { Second } \\
\text { formative } \\
\text { evaluation } \\
\text { Vs post test }\end{array}$ & $\begin{array}{l}\text { Pre-test Vs } \\
\text { post test }\end{array}$ & & \\
\hline $\begin{array}{l}\text { I use learning } \\
\text { contracts. Grouping } \\
\text { activities, independent } \\
\text { studies, questioning, } \\
\text { interest groups and } \\
\text { centers to differentiate } \\
\text { instruction that appeal } \\
\text { to various learning } \\
\text { style or preferences } \\
\end{array}$ & $10(50.0 \%)$ & $5(25.0 \%)$ & $18(90.0 \%)$ & $20(100.0 \%)$ & $7(35.0 \%)$ & $\begin{array}{l}\chi 2=19.259 \\
P<0.001\end{array}$ \\
\hline
\end{tabular}


The Effect of Pedagogical Knowledge Training on the Development of Inclusive Practices for Primary School Teachers: The Case of Buea Sub-Division, South West Region of Cameroon

\begin{tabular}{|c|c|c|c|c|c|c|}
\hline $\begin{array}{l}\text { I give pupils different } \\
\text { choices, and create } \\
\text { alternative activities }\end{array}$ & $7(35.0 \%)$ & $4(20.0 \%)$ & $18(90.0 \%)$ & $19(95.0 \%)$ & $4(40.0 \%)$ & $\begin{array}{l}\chi 2=15.481 \\
P<0.001\end{array}$ \\
\hline $\begin{array}{l}\text { I use multiple ways of } \\
\text { representing content } \\
\text { (visual and oral } \\
\text { strategies) }\end{array}$ & $10(50.0 \%)$ & $5(25.0 \%)$ & $16(80.0 \%)$ & $17(85.0 \%)$ & $5(25.0 \%)$ & $\begin{array}{l}\chi 2=17.688 \\
P<0.001\end{array}$ \\
\hline $\begin{array}{l}\text { Pupils use multiple } \\
\text { means to express } \\
\text { content (writing, } \\
\text { illustrating, and } \\
\text { speaking) }\end{array}$ & $9(45.0 \%)$ & $5(25.0 \%)$ & $14(70.0 \%)$ & $17(58.0 \%)$ & $5(25.0 \%)$ & $\begin{array}{l}\chi 2=16.053 \\
P<0.001\end{array}$ \\
\hline $\begin{array}{l}\text { I use flexible means of } \\
\text { engaging my pupils } \\
\text { learn (modeling and } \\
\text { role playing) }\end{array}$ & $10(50.0 \%)$ & $6(30.0 \%)$ & $16(80.0 \%)$ & $19(95.0 \%)$ & $3(15.0 \%)$ & $\begin{array}{l}\chi 2=26.636 \\
P<0.001\end{array}$ \\
\hline $\begin{array}{l}\text { I provide opportunities } \\
\text { for pupils to work in } \\
\text { small groups and in } \\
\text { pairs }\end{array}$ & $7(35.0 \%)$ & $5(25.0 \%)$ & $15(75.0 \%)$ & $19(95.0 \%)$ & $6(30.0 \%)$ & $\begin{array}{l}\chi 2=18.560 \\
P<0.001\end{array}$ \\
\hline $\begin{array}{l}\text { I provide supports or } \\
\text { scaffolds to pupils as } \\
\text { they are learning new } \\
\text { material }\end{array}$ & $9(45.0 \%)$ & $4(20.0 \%)$ & $17(85.0 \%)$ & $17(85.0 \%)$ & $3(15.0 \%)$ & $\begin{array}{l}\chi 2=20.752 \\
P<0.001\end{array}$ \\
\hline $\begin{array}{l}\text { I employ active } \\
\text { learning strategies } \\
\text { such as they "think, } \\
\text { pair, share" to promote } \\
\text { recall and } \\
\text { understanding of new } \\
\text { learning }\end{array}$ & $8(40.0 \%)$ & $7(35.0 \%)$ & $14(70.0 \%)$ & $19(95.0 \%)$ & $6(30.0 \%)$ & $\begin{array}{l}\chi 2=18.760 \\
P<0.001\end{array}$ \\
\hline MRS & $70(43.8 \%)$ & $41(25.6 \%)$ & $128(80.0 \%)$ & $147(91.9 \%)$ & $43(26.9 \%)$ & $\begin{array}{l}\chi 2=17.29 \\
P<0.001\end{array}$ \\
\hline
\end{tabular}

Research hypothesis two: Knowledge of classroom assessment does not influence teachers' ability to set high expectations for all learners in ordinary classrooms.

Comparing progression between pre-test and post-test for Knowledge on classroom assessment

Table6. Comparing progression between pre-test and post-test for Knowledge on classroom assessment

\begin{tabular}{|c|c|c|c|c|c|c|}
\hline \multirow{3}{*}{$\begin{array}{l}\text { Knowledge on } \\
\text { classroom } \\
\text { assessment }\end{array}$} & \multicolumn{5}{|c|}{$\begin{array}{l}\text { Cumulative progression (in percentage of those with positive change } \\
\text { in score) }\end{array}$} & \multirow{3}{*}{$\chi^{2 \text {-test }}$} \\
\hline & \multicolumn{4}{|c|}{ Experimental group $(\mathrm{N}=\mathbf{2 0})$} & \multirow{2}{*}{$\begin{array}{l}\begin{array}{l}\text { Control } \\
\text { group } \\
(\mathrm{N}=20)\end{array} \\
\begin{array}{l}\text { Pre-test Vs } \\
\text { post test }\end{array}\end{array}$} & \\
\hline & $\begin{array}{l}\text { Pre-test to } \\
\text { first } \\
\text { formative }\end{array}$ & $\begin{array}{l}\text { First } \\
\text { formative } \\
\text { to second } \\
\text { formative }\end{array}$ & $\begin{array}{l}\text { Second } \\
\text { formative } \\
\text { evaluation } \\
\text { Vs post test }\end{array}$ & $\begin{array}{l}\text { Pre-test Vs } \\
\text { post test }\end{array}$ & & \\
\hline $\begin{array}{l}\text { I use pre-assessment, } \\
\text { brainstorming and } \\
\text { 'listening while you } \\
\text { work' techniques to } \\
\text { help inform } \\
\text { instruction and } \\
\text { monitor pupils' } \\
\text { progress }\end{array}$ & $8(40.0 \%)$ & $6(30.0 \%)$ & $18(90.0 \%)$ & $18(90.0 \%)$ & $9(45.0 \%)$ & $\begin{array}{l}\chi 2=13.333 \\
P<0.001\end{array}$ \\
\hline $\begin{array}{l}\text { I make it clear to } \\
\text { pupils what will be } \\
\text { tested in different } \\
\text { types of assignment, } \\
\text { and how and why, at } \\
\text { the beginning of the } \\
\text { lesson }\end{array}$ & $7(35.0 \%)$ & $8(40.0 \%)$ & $18(90.0 \%)$ & $19(95.0 \%)$ & $7(35.0 \%)$ & $\begin{array}{l}\chi 2=16.872 \\
P<0.001\end{array}$ \\
\hline
\end{tabular}




\begin{tabular}{|c|c|c|c|c|c|c|}
\hline $\begin{array}{l}\text { I explain clearly with } \\
\text { model answers, what } \\
\text { is expected of my } \\
\text { pupils }\end{array}$ & $8(40.0 \%)$ & $5(25.0 \%)$ & $17(85.0 \%)$ & $18(90.0 \%)$ & $6(30.0 \%)$ & $\begin{array}{l}\chi 2=15.164 \\
P<0.001\end{array}$ \\
\hline $\begin{array}{l}\text { I make reasonable } \\
\text { adjustments to all } \\
\text { types of assessment } \\
\text { to make them more } \\
\text { accessible to all } \\
\text { pupils in my class }\end{array}$ & $8(40.0 \%)$ & $4(20.0 \%)$ & $16(80.0 \%)$ & $18(90.0 \%)$ & $6(30.0 \%)$ & $\begin{array}{l}\chi 2=17.200 \\
P<0.001\end{array}$ \\
\hline $\begin{array}{l}\text { I make reasonable } \\
\text { adjustments to } \\
\text { minimize periods of } \\
\text { intense on struggling } \\
\text { learners }\end{array}$ & $7(35.0 \%)$ & $5(25.0 \%)$ & $17(85.0 \%)$ & $18(90.0 \%)$ & $6(30.0 \%)$ & $\begin{array}{l}\chi 2=17.200 \\
P<0.001\end{array}$ \\
\hline $\begin{array}{l}\text { I focus on learning } \\
\text { rather than marks in } \\
\text { order to provide } \\
\text { opportunities for } \\
\text { pupils to reflect on } \\
\text { their progress }\end{array}$ & $9(45.0 \%)$ & $6(30.0 \%)$ & $17(85.0 \%)$ & $19(95.0 \%)$ & $6(30.0 \%)$ & $\begin{array}{l}\chi 2=18.760 \\
P<0.001\end{array}$ \\
\hline $\begin{array}{l}\text { I link pupils' } \\
\text { assessments to their } \\
\text { individual learning } \\
\text { outcomes }\end{array}$ & $6(30.0 \%)$ & $6(30.0 \%)$ & $16(80.0 \%)$ & $18(90.0 \%)$ & $4(20.0 \%)$ & $\begin{array}{l}\chi 2=20.017 \\
P<0.001\end{array}$ \\
\hline $\begin{array}{l}\text { I give different forms } \\
\text { of feedback to } \\
\text { facilitate discussions } \\
\text { between my pupils } \\
\text { and I }\end{array}$ & $10(50.0 \%)$ & $5(25.0 \%)$ & $17(85.0 \%)$ & $18(90.0 \%)$ & $3(15.0 \%)$ & $\begin{array}{l}\chi 2=23.492 \\
P<0.001\end{array}$ \\
\hline MRS & $193(39.4 \%)$ & $45(28.1 \%)$ & $136(85.0 \%)$ & $146(91.3 \%)$ & $47(29.4 \%)$ & $\begin{array}{l}\chi 2=15.00 \\
P<0.001\end{array}$ \\
\hline
\end{tabular}

Results from data analyses revealed that there was a significant correlation between teachers' knowledge of classroom management and the establishment of routines that free up time for small groups and individual instructions in ordinary classrooms. The null hypothesis stated above was then rejected. To come up with the significance of this hypothesis, teachers' knowledge of classroom management was tested using four different evaluations. The results indicated that there was a noticeable progression between the pre-test and the post-test. The significant progression is theoretically supported by Embracing Diversity: Toolkit for Creating Inclusive Learning-Friendly Environments (UNESCO Bangkok, 2004) which is a toolkit that promotes and provides guidance on how to create an inclusive, learning-friendly environment (ILFE), which welcomes, nurtures, and educates all children regardless of their gender, physical, intellectual, social economic, emotional, linguistic, or other characteristics. In line with the professional development of practicing teachers, Siebert (2005) is of a contrary view and argues that teacher educators insist that their preparation programmes teach classroom organization and behaviour management skills, but the indication is that such skills are not taught thoroughly or with adequate supervision in a real classroom context. Berliner, 1986; Espin \& Yell (1994) are of the opinion that the absence of supervised experience and professional development in the critical competencies of classroom organization and behaviour management significantly reduces the effectiveness of many teachers, especially new teachers.

The second hypothesis showed that there was a significant correlation between teachers' knowledge of classroom assessment and their ability to set high expectations for all learners in ordinary classrooms. The null hypothesis was therefore rejected and the alternative accepted. To come up with the significance of this hypothesis, the component "knowledge of classroom assessment" was tested using eight different indicators with four evaluations carried out. Results from all indicators of this component showed that there was a noticeable progression between the pre-test and the post-test levels but the progression coefficient dropped between the first formative evaluation and the second formative evaluation. This drop was noticed because teachers did not receive any training between the two test levels.

This noticeable progression between the pre-test and the post-test is supported by a survey of in-service teachers carried out by Stiggins in 1991. He found that approximately $50 \%$ to $75 \%$ of 
in-service teachers have taken at least one course in measurement and evaluation, as a part of their undergraduate or graduate professional preparation programme. Less than $1 \%$ of that population said that their course work in this area has provided them with a "relevant and helpful experience in terms of preparing them to meet the day to day demands of classroom assessment,".

Results from the follow-up carried out by me after the training programme indicated that the teachers set high expectations for all learners in ordinary classrooms. Chapman \& King (2012) argues that when assessing students in the differentiated class, it is essential that assessment should be authentic; meaning that it offers students a variety of tasks demonstration in real-life skills, tells the educator if the student has acquired the skills or concepts, is based on standard criteria to achieve validity, and guides students for roles in adult life. As teachers face classrooms that are composed of a broad range of students, representing a wide variety of educational needs, one response to addressing students' varied academic needs is the philosophy of differentiation.

\section{COMPARISON BETWEEN THE EXPERIMENTAL AND THE CONTROL GROUPS}

Ordinary school teachers who took part in the study were without randomization assigned to two groups (experimental and control groups). Those who received training in pedagogical knowledge as mentioned in the training procedure in page 108 above, were assigned to the experimental group and those who did not were used as a control group. Results from the comparison of the two groups across the test levels (pre-test-post-test) indicated that the teachers who received training (experimental group) performed better than those who did not receive the training (control group). These results are indicative because they go in line with an earlier research conducted by Desimone et al. (2002). Their findings indicated that teachers believed that a range of professional development sessions had an impact on them.

\section{RECOMMENDATIONS}

The researcher has argued in this research that ordinary school teachers may need more explicit and intensive instruction in smaller group settings in order conceptualized inclusive education and practice it in school settings. Therefore, teacher trainers should take as a matter of responsibility the integration of pedagogical knowledge training for inclusion in teacher training programmes. The study has also shown that when this is done effectively it will result in an improvement in pedagogical skills that will eventually lead to inclusive best practices in our ordinary school. It is against this background that the recommendations below are made.

- Basic education authorities could send a strong administrative message to the staff that they work collaboratively to affect positive changes in their daily practices.

- School administrators could create and nurture a culture in which pedagogical knowledge training for inclusive practices would be an important and ongoing component of the curriculum that benefits all teacher trainees.

- When preparing school programmes teachers could take into consideration the learning characteristics of children with special educational needs. Consideration could also be made on the fact that pedagogical knowledge training take much time, efforts, and practice to be effective.

- Systematic assessment before starting any training programme could also be made by teacher trainers. This will help in adjusting pedagogical instructions to meet the needs of all teachers in ordinary schools. Assessment data will help in determining the nature of performance deficits so that the right intervention techniques can be utilized.

- There is no one intervention technique to train a particular pedagogical knowledge. Different training techniques could be used by teacher trainers when conducting pedagogical knowledge training programmes and these techniques should vary based on the teachers' pattern of deficits.

\section{CONCLUSION}

Pedagogical Skill training has become a popular adjunct treatment for developing pedagogical skills that will lead to inclusive best practices in ordinary schools. Presently, pedagogical knowledge training is best viewed as an experimental intervention. The theoretical structure of pedagogical knowledge is incomplete resulting in problems in definition, measurement, and design. Specifically, 
further research is necessary to resolve issues regarding for example, duration of training, assessment instruments, packaging of training programmes, and contextual variables. The results of this study indicated that if ordinary school teachers who took part in the training were not trained in pedagogical knowledge this deficit will continuously leads to academic, social and emotional problems that will have negative effects on children with special educational needs in ordinary schools. From the study it was then concluded that the use of pedagogical knowledge training or instructions by teacher trainers could result in improved in-service teachers' abilities to establish routines that free up time for small groups and individual instructions, set high expectations for all learners in ordinary classrooms, clearly communicate expectations that engage all learners in learning, spend adequate time on learners who are struggling and develop collaborative ways of working by teachers. The researcher is of the opinion that pedagogical skill training which can improve pedagogical skills for inclusive practices should not be 'razed' or 'remodeled,' but instead 'rebuilt' as part of the component of the initial training of both pre-service and in-service teachers. Until the rebuilding process is complete, pedagogical knowledge training is best viewed as an intervention that has received limited empirical support but, nevertheless holds promise for improving the pedagogical skills for best practices in inclusive education.

\section{REFERENCES}

Abdallah, O. (1998). The attitudes of teachers and principals of basic schools towards mainstreaming handicapped students in general. Unpublished M.A. Dissertation. Al- Njah National University. Nablus. Palestine.

Al Tarwana, N. (2008). Pre-service teachers' attitudes toward teacher preparation. Unpublished Doctoral Dissertation. Jordan.

Alur, M. and Timmons, V. (2005c). Culturally Appropriate Policy and Practices III. Mumbai, India: National Resource Centre for Inclusion.

Amin, M. E. (2005). Social science research: Conception, methodology \& analysis. Kampala, Makerere University Printery.

Baker, P. H. (2005). Managing student behavior: How ready are teachers to meet the challenge? American Secondary Education, 33(3), 51-64.

Bean, M. R and Morewood, L. A. (2006). "Teachers- Perceptions of the Influence of Professional Development on Their Knowledge of Content, Pedagogy, and Curriculum", College Reading Association Yearbook, 31, pp.201-219.

Bean, R. (2004). The reading specialist: Leadership for the classroom, school, and community. New York, NY: Guilford Press.

Bennett, T., Deluca, D., \&Bruns, D. (1997, Fall). Putting inclusion into practice: Perspectives of teachers and parents.Exceptional Children, 64:1, 115-131.

Blanton, L. P., Pugach, M. C. \& Florian, L. (2003).Preparing general educators to improve outcomes for students with disabilities. Washington, DC: American Association of Colleges of Teacher Education and National Council for Learning Disabilities.

Boe, E., Cook, H., \& Shin, S. (2007). Does teacher preparation matter for beginning teachers in either special or general education? Journal of Special Education, 41,158-170.

Boom, B. S (ed.) (1956) Taxonomy of Educational Objectives, the classification of educational goals - Handbook I: Cognitive Domain. New York: McKay

Bransford, J. D., Brown, A. L., \& Cocking, R. R. (2000).How people learn: Brain, mind, experience, and school.Washington, DC: National Academy Press.

Breakwell, G. M., Hammond, S., \&Fiffe-Schaw, C. (2004).Research methods in psychology. London: Sage Publications.

Brown, K.S., Welsch, K.H.H., \&Cipko, J.P. (2008). The efficacy of embedding special education instruction in teacher preparation programs in the United States. Journal of Teaching and Teacher Education, 24, 2087-2094.

Bruner, J. S. 1966. Toward a Theory of Instruction. Cambridge MA: Harvard University Press.

Campbell, J., Gilmore, L., \&Cuskelly, M. (2003). Changing students teachers' attitudes towards disability and inclusion. Journal of Intellectual and Developmental Disability, 28, 369-379. 
The Effect of Pedagogical Knowledge Training on the Development of Inclusive Practices for Primary School Teachers: The Case of Buea Sub-Division, South West Region of Cameroon

Chapman, C. \& King, R., (2012).Differentiated assessment strategies: One tool doesn't fit all, second edition. Thousand Oaks, California: Corwin Press.

Chick, H. Baker, M. Pham, T., \& Cheng, H. (2006). Aspects of teachers' pedagogical content knowledge for decimals. Manuscript submitted for publication.

Choles, M. (2000).Attitudes of South African teacher educators in relation to mainstreaming pupils with special educational needs. Unpublished M.A Dissertation, University of the Witwatersrand.

Clotfelter, C. T., Ladd, H.F., Vigdor, J. L., \& Wheeler, J. (2007).High-poverty Educational.Research. Washington, DC: National Center for Analysis of Longitudinal Data in Educational Research

Dunn, R., Griggs, S. A., Olson, J., Gorman, B., Beasley, M. (1995).A meta-analytic validation of the Dunn and Dunn learning styles model.Journal of Educational Research, 88(6), 353-62.

Elloker, S. (1999).Inclusive education as a strategy to develop effective schools: A case study of a primary school in a socio-economic disadvantaged environment. Unpublished M.A Dissertation, University of the Western Cape.

Emmer, E.T. and Stough, L. M. (2001). Classroom Management: A Critical Part of Educational Psychology, With Implications for Teacher Education. Educational Psychologist, Volume 36, Issue 2, 2001, pp.103-112.

Firestone, W. A., \& Pennell, J. R. (1997).Teacher commitment, working conditions, and differential incentive policies.Review of Educational Research,63 (4), 489-525.

Florian, L., \& Rouse, M., (2009) The inclusive practice project in Scotland: Teacher education for inclusive education. Teaching and Teacher Education 25(4), 594-601.

Florio-Ruane, S., Raphael, T.E., Highfeild, K., \& Berne, J. (2004).Reengaging youngsters with reading difficulties by means of innovative professional development. In D.S. Strickland \& M.L. Kamil (Eds.), Improving Reading Achievement Through Professional Development (pp.129147). Norwood, MA: Christopher-Gorden.

Forgacs, R. T. (2012). 'Strengthening Teacher Education to Achieve EFA by 2015: How are student teachers prepared to adopt inclusive attitudes and practices when they start teaching?' Consultancy report, UNESCO.

Forlin, C,.and Chambers, D. (2001). Teachers preparation for inclusive education: Increasing knowledge but raising concerns. Asia-Pacific Journal of Teacher Education, Vol. 39, N0. 1, pp. 17-32.

Fraenkel, J. R. \&Wallen, N. E., (2000).How to design \& evaluate research in education.Boston: MGraw-Hill.

Franzke, M., Kintsch, E., Caccamise, D., Johnson, N., \& Dooley, S. (2005). Summary Street: Computer Support for Comprehension and Writing. Journal of Educational Computing Research, 33, 53-80.

Froyen, L.A., and Iverson, A.M. (1999). School wide and Classroom Management: The Reflective Educator-Leader. Upper Saddle River, N.J.: Prentice-Hall.

Gary, D. B. (1997).Educational psychology: a contemporary approach. Longman, Michigan.

Glaser, C., \&Brunstein, J. (2007).Improving fourth-grade students' composition skills: effects of strategy instruction and self-regulation procedures.Journal of Educational Psychology, 99(2), 297-310. doi: 10.1037/0022-0663.99.2.297.

Gordon, C. (2002).Attitudes of teachers with experience in exclusive education towards inclusion. Unpublished M.A Dissertation, University of the Witwatersrand.

Greenwood, C.R. (2002). Academic engagement: Current perspectives on research and practice. School Psychology Review, Vol. 31, No. 3, pp 299-328.

Grossman P.L., Richert A. E (1998). Unacknowledged Knowledge Growth: A Re-Examination of the Effects of Teacher Education. http://dx.doi.org/10.1016/0742-051X\%2888\%29900248Teaching and Teacher Education, Volume 4, Issue 1, pp.53-62.

Grossman, P. L. (1991). Mapping the terrain: Knowledge growth in teaching. In H. Waxman \& H. Walberg (Eds.), Contemporary research on teaching. Chicago: National Society for the Study of Education, pp. 203-215. 
Guild, P. B.,\&Garger, S. (1985). Marching; to different drummers, Alexandria, VA: Association for Supervision and Curriculum Development.

Gullickson, A, R. and Hopkins, K. D. (1987). The Context of Educational Measurement Instruction for Pre-service Teachers: Professor Perspectives. Educational Measurement: Issues and Practice, 12-16.

Hardman, F. (2011).A Review of Save the Children's Global Teacher Support and Development Interventions. London: Save the Children Global Alliance.

Hardman, F., \&Stoff, C. (2012).Baseline Study Child-Centred Approaches and Teaching and Learning Practices in Selected Primary Schools in Child-Friendly School Focused Townships in Myanmar. Paris: UNICEF.

Harrell, P., Leavell, A., van Tassell, F., \& McKee, K. (2004). No teacher left behind: Results of a five-year study of teacher attrition. Action in Teacher Education, 26,47-59.

Hashweh, M. Z. (2005). Teacher pedagogical constructions: A reconfiguration of pedagogical content knowledge. Teachers and Teaching: Theory and Practice, 11(3), 273-292.

Hattie, J. and Timperley, H. (2007).The power of feedback. Review of Educational Research. Vol. 77, No. 1, pp. 81-112.

Imerovic, S. (2006). 'Changing the way we teach, Burkina Faso'. Enabling Education, Issue 10 (Special Edition: teacher education):. 12-13

Ingersoll, R. M. and Smith, T.M. (2003).The wrong solution to the teacher shortage. Educational Leadership, Vol 60, no. 8, pp. 30-38.

Ivey, J.K. \&Reincke, K. (2002).Pre-service teacher's attitudes toward inclusion in a non-traditional class.Electronic Journal of Inclusive Education. Oklahoma State University.

Kansanen, P. (2002). Didactics and its relation to educational psychology: Problems in translating a key concept across research communities. International Review of Education, 48(6), 427-441.

Kearn, H. \&Shevlin, M. (2006). Initial teacher preparation for special educational needs: Policy and Practice. Teacher Development, 10 (1) 25-42.

Kellaghan, T. Madaus, G.F. and Airasian, W.A. (1982).The effects of standardized testing. Boston: M. Nijhoff.

Kellam,S.G. Ling, X. Merisca, R. Brown, C.H. Ialongo, N. (1998).. The effect of the level of aggression in the first grade classroom on the course and malleability of aggressive behavior into middle school. Development and psychopathology 10 (02), 165-18.

Kgare, D. (2000). The role of education support services in the implementation of inclusive education.Unpublished M.A Dissertation, Rand Afrikaans University.

Kramarski, B. \&Zeichner, O. (2001).Using technology to enhance mathematical reasoning: Effects of feedback and self-regulation learning. Educational Media International, 38(2/3), 77-82.

Kumar, R. (2005). Research methodology: A step-By-Step Guide for Beginners. New Delhi: India Darling Kindersley.

Kyriakides, L., \&Creemers, B.P.M. (2008).A longitudinal study on the stability over time of school and teacher effects on student learning outcomes.Oxford Review of Education, 34(5), 521-545.

Lefever-Davis, S., Wilson C., Moore E., Kent, A., and Hopkins, S. (2003). Teacher study groups: a strategic appraoch to promoting students' literacy development. The Reading Teacher, 56(8), 782-784.

LeRoy, B., \& Simpson, C. (1996).Improving student outcomes through inclusive education. Support for Learning, 11, pp 32-36.

Leyser,Y. Tappendorf, K. (2001). Are attitudes and practices regarding mainstreaming changing? A case of teachers in two rural school districts. Education, 121(4),751-761.

Ljubetić, M. \&Kostović-Vranješ, V. (2008).Pedagogical (in) competence of teachers. Educational science, 10, 1, 209-230.

Makunga, N. (2002). Educator's perceptions of inclusive education for the hearing impaired learner. Unpublished M.A. Dissertation. University of Zululand.

Mathan, S.A. and Kenneth R. Koedinger, K. E (2002). An empirical assessment of comprehension fostering features in an intelligent tutoring system. Educational Psychologist, 40(4), 257-265. 
The Effect of Pedagogical Knowledge Training on the Development of Inclusive Practices for Primary School Teachers: The Case of Buea Sub-Division, South West Region of Cameroon

Mattsson, M., Dage Ore, H. and Pisila, S. (2006) Vadärvärdefullspecialpedagogiskkunskap?[What knowledge is of value in Special Education?] Stockholm: Lärarhögsk

Mayo, S.T. (1967). Pre-service preparation of teachers in educational measurement. Final report (Project No. 5- 0807). Washington, D.C Office of Education (DHEW), Bureau of Research.

McHoton, P., \&McCary, E. Inclination toward inclusion: Perceptions of elementary and secondary education teacher candidates. Action in Teacher Education.29, 25-32.

Mcleskey, J. \& Waldron, N.L. (2002). Inclusion and school change: Teacher perceptions regarding curriculum and instructional adaptations. Teacher education and special education. 25 (1), 4154.

Miles, S. (2009). 'Engaging with teachers' knowledge: Promoting inclusion in Zambian schools'. Disability \& Society, 24(5): 611-624.

Miller DL, Kelley ML. The use of goal setting and contingency contracting for improving children's homework performance. Journal of Applied Behavior Analysis. Vol. 27, pp. 73-84.

Mitchell, D. (2008). What Really Works in Special and Inclusive Education: Using evidence based teaching strategies. London: Routledge.

Mooney, N., Bauman, A., Westwood, B., Kelaher, B., Tibben, B.\&Jalaludin, B.(2005).A quantitative evaluation of Aboriginal cultural awareness training in an urban health service. Aboriginal and Islander Health Worker Journal.29(4):23-30.

Morine-Dershimer, G. and Kent, T. (1999). 'The Complex Nature and Sources of Teachers' Pedagogical Knowledge' in Examining Pedagogical Content Knowledge, Dordrecht: Kluwer Academic Publishers.

Mowes, D. (2000). The attitudes of educators in Namibia towards inclusive education. Unpublished Doctoral Dissertation, University of Stellenbosch.

Mubazi, J. K. (2008). Research methods. Kampala: Makerere University Printery.

Nilsson, P. (2008). Learning to Teach and Teaching to Learn : Primary science student teachers complex journey from learners to teachers. LiU-Tryck, Linköping University Press, Linköping, Sweden. No. 1, pp. 17-32.

Ntombela, S. (2009) Are we there yet? Towards the development of inclusive education in one district of KwaZulu-Natal, South Africa. The International Journal of Learning, 374 (9704), 1795-1796.

O'Sullivan, M.C., (2010). 'Educating the teacher educator: A Ugandan case study'. International Journal of Educational Development, (30)5, 377-387.

Ogle, D. M (1986). K-W-L: A Teaching Model That Develops Active Reading of Expository Text. The Reading Teacher, Vol. 39, No. 6, pp. 564-570.

Oladele.J.O. (1989).Fundamentals of Psychological foundations of Education. (3rded.) Lagos: Johns Lad Publishers Ltd.

Oso, W. Y. \&Onen, D. (2008).A general guide to writing research proposal and report: A handbook for beginning researchers $\left(2^{\text {nd }}\right.$ ed.). Kampala :Makerere University Press.

Oyler, C. (2011). Preparing teachers of young children to be social justice-oriented educators. In A. L. Goodwin, \& B. Fennimore (Eds.) Promoting social justice for young children: Facing critical challenges to early learning and development. New York: Springer.

Page-Voth, V. \& Graham, S. (1999). Effects of goal-setting and strategy use on the writing performance and self-efficacy of students with writing and learning problems.Journal of Educational Psychology, 91,230-240.

Parasuram, K. (2006).Variables that affect teachers' attitudes towards disability and inclusive education in Mumbai, India.Disability \& Society, Vol, 21, No.3, pp. 231-242.

Pearce, M., Gray, J., \& Campbell-Evans, G. (2009). The Inclusive Secondary Teacher: The Leaders' Perspective.Australian Journal ofTeacher Education, 34(6).

Perner, D. and Porter, G. (2008). 'Creating Inclusive Schools: Changing roles and strategies'. PowerPoint from Research Based Practices in Developmental Disabilities. http://www.inclusioneurope.

Pintrich, P. R., \&Schunk, D. H. (2002).Motivation in education: Theory,research, and applications (2nd ed.). Upper Saddle River, NJ: Prentice Hall. 
Power, S. Aggleton, P. Brannen, J. Brown, A. Chisholm, L. and Mace, J.(Eds), A Tribute to Basil Bernstein 1924-2000. London: Institute of Education.

Premack, D. (1965). Reinforcement theory. In D. Levine (Ed.),Nebraska Symposium on Motivation (Vol. 13, pp. 123-180).Lincoln: University of Nebraska.

Ramsden, P. (2006). Evaluation of education programmes. Save the Children UK, Mongolia

Roberts, J.J. (2011). 'Educators' experiences of their training for the implementation of Screening,, Identification,, Assessment and Support strategy at a full-service school:: A case study.' Masters in Educational Psychology Thesis, North West University, RSA.

Ronald, M. N., and Fred, P. L. (1993, February).Outstanding teachers' sense of teacher efficacy at four stages of career development. Paper presented at the Annual Conference of the Association of Teacher Educators, Los Angeles.

Ross, J., \& Bruce, C. (2007). Professional development effects on teacher efficacy: Results of randomized field trial. The Journal of Educational Research, 101(1), 50-60.

Schlauch, D. (2003). A cross-sectional study of preservice and beginning teachers'attitudes and feelings of preparedness to work with students with disabilities.(Doctoral dissertation) Retrieved from ProQuestDissertations and Theses.

Sharma, U,. Moore, D., and Sonawane, S. (2009). Attitudes and concerns of pre-service teachers regarding inclusion of students with disabilities into regular schools in Pune, India.Asia-Pacific Journal of Teacher Education, Vol. 37,. No. 3, pp. 319-331.

Shippen, M., Crites, S., Houchins, D, Ramsey, M., Simon, M. (2005). Pre-service teachers' perceptions of including students with disabilities.Teacher education and Special Education, 28 (2), 92-99.

Shirbagi, N. (2007). Exploring Organizational Commitment and Leadership Frames within Indian and Iranian Higher Education Institutions. Bulletin of Education \& Research, Vol. 29

Shpiro, A. (2009). Everybody belongs: Changing negative attitudes toward classmates with disabilities. New York: Garland Publishing.

Shulman, L. S. (1987). Knowledge and teaching: Foundations of the new reform. Harvard Educational Review, 57(1), 1-22

Shulman, L.S. (1986). "Those Who Understand: Knowledge Growth in Teaching," Educational Researcher. 15 (2), 4-14.

Siebert, C. J. (2005). Promoting preservice teacher's success in classroom management by leveraging a local union's resources: A professional development school initiative .Education, 125,385-392.

Skinner, B. F. (1938). The behavior of organisms: an experimental analysis.

Sparks, D. \&Loucks-Horsley, S. (1990). Models of Staff Development. In Houston, R. (Ed.), Handbook of Research on Teacher Education. (pp.234-250) New York: Macmillan Publishing Co.

Sruggs, T.E., Mastropieri, M.A., and Mcduffie, K.A. (2007). Co-teaching in inclusive classrooms: A metasynthesis of qualitative research. Exceptional Children, Vol. 73, No. 4, pp.392-416.

Stubbs, S. (1995). 'The Lesotho National Integrated Education Programme: A Case Study on Implementation'.http://www.eenet.org.uk/resources/docs/Lesotho_National_IEP_Stubbs_thesis. doc

Stubbs, S. (2011). 'An Overview of International Practice in Teacher Education for Inclusion'. A background paper prepared for UNICEF Macedonia.

Subban, P. (2005).Primary school teachers' perceptions of inclusive education in Victoria, Australia. International Journal of Special Education, 21(1), 42-52.

Tomlinson, C. (1995). How to differentiate instruction in mixed-ability classrooms. Alexandria, VA: Association for Supervision and Curriculum Development. ED 386301.

Tomlinson, C. A. (2001). How to differentiate instruction in mixed-ability classrooms. Alexandria, Virginia: Association for Supervision and Curriculum Development.

Tomlinson, K. Ridley, K.F. Fletcher-Campbell. (2004). Evaluation of UNESCO's programme for the inclusion of children from various marginalised groups within formal Education programmes: Final report, UNESCO Press. Paris 
The Effect of Pedagogical Knowledge Training on the Development of Inclusive Practices for Primary School Teachers: The Case of Buea Sub-Division, South West Region of Cameroon

Trevisan P. (2002). Orvosokèsszentekközött, in Olaszorsàgedited by PrónaiCsaba, ÙjMandàtum, Budapest, pp. 415-439.

Udvari-Solner, A., Villa, R.A., \& Thousand, J.S. (2005). Access to the general educationcurriculum for all: The universal design process. In R.A. Villa \& J.S. Thousand, Creating an inclusive school (2nd ed.) (pp. 134-155). Alexandria, VA: Association for Supervision and Curriculum Development.

UNESCO (1993).Educating Children and Young People with Disabilities: Principles and the review of practice. Paris: UNESCOhttp://unesdoc.unesco.org/images/0009/000955/095511eo.pdf

UNESCO (1995).Las necesidadeseducativasespeciales. Conjunto de materialespara la formación de profesores.París: UNESCO.

UNESCO (2004).Changing Teaching Practices. Using differentiation to respond to students' diversity.Paris:UNESCO.http://unesdoc.unesco.org/images/0013/001365/136583e.pdf

UNESCO (2009) Policy Guidelines on Inclusion in Education. UNESCO: Paris. http://unesdoc.unesco.org/images/0017/001778/177849e.pdf

UNESCO.(1994). Salamanca statement. Paris: UNESCO.

Van Staden, J. (2001). Teacher's responses to the challenges of inclusive education. Unpublished M.A. Dissertation. Rand Afrikaans.

Wagner, M., Kutash, K., Duchnowski, A. J., Epstein, M. H., \&Sumi, W. C. (2005). The children and youth we serve: A national picture of the characteristics of students with emotional disturbances receiving special education. Journal of Emotional and Behavioral Disorders, 13 (2), 79-96.

WHO (2010).Community Based Rehabilitation CBR Guidelines: Education. New York: World HealthOrganisationhttp://whqlibdoc.who.int/publications/2010/9789241548052_education_eng. pdf

WHO.(2011). World report on disability. New York: WHO.

Wilczenski, F.L. (1992). Development of a scale to measure attitudes toward inclusive education. Educational and Psychological Measurement, 55(2), 291-299.

Wolery, M. Anthony, L., Snyder, E. D., Werts, M. G.,\&Katzenmeyer, J. (1997). Training elementary teachers to embed instruction during classroom activities. Education and Treatment of Children, $20,40-58$.

\section{AUTHOR's BIOGRAPHY}

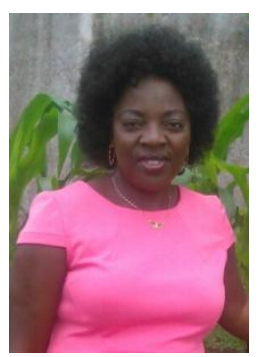

Dr. Ambei Ruhama Faizefu Epse Luma, is a teacher of Special Needs Education at the University of Buea and the Chief of Service for Administrative Finance at Government Teacher Training College Buea, Cameroon. Ambei Ruhama Faizefu has a $\mathrm{PhD}$ in Special Needs Education with a Double Concentration in Inclusive Education and Learning Disabilities. She has a Master's Degree (M.Ed) in Curriculum Development and Applied Linguistics, a Higher Teacher Grade One Diploma (DIPEN II) In Sciences of Education and a Bachelor's Degree B.A (Hons) in English Modern Letters. Amongst her numerous publications is "English Grammar Series in a TEFL Classroom". Dr. Ambei Ruhama Faizefu Epse Luma is a renowned Researcher working with: Foundation of Scientific Research, Community Based Rehabilitation and Advocacy on Inclusive Education" (FORCAIE-Cameroon). 